\title{
ПОЧАТКОВА ОСВITА
}

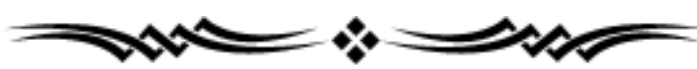

DOI 10.31651/2524-2660-2020-4-207-212

ORCID 0000-0001-8480-2702

\section{РОМАНИШИН Руслана Ярославівна,}

кандидатка педагогічних наук, доцентка кафедри фахових методик і технологій початкової освіти, ДВНЗ "Прикарпатський національний університет імені Василя Стефаника" e-mail: ruslanaromanyshyn@ukr.net

УДК $378: 159.9: 519.6(045)$

\section{ФОРМУВАННЯ ОБЧИСАЮВАМЬНОЇ НАВИЧКИ В УЧНІВ ПОЧАТКОВОЇ ШКОАИ В УМОВАХ РОЗВИВААЬНОГО НАВЧАННЯ}

На основі аналізу науково-методичних джерел розглянуто проиес засвоєння змісту обчислювальної діяльності та формування на його основі обчислювальних умінь і навичок є складним та тривалим проиесом.

Висвітлено теоретичні засади розвивального навчання з точки зору діяльнісної теорії. Відмічається відмінність між проиесом формування обчислювальних навичок у традииійній системі навчання та системі розвивального навчання. Зазначаються характерні особливості систем 1. Занкова, В. Давидова та Д. Эльконіна, Н. Істоміної. У результаті аналізу називаються ефрективні стратегії для формування обчислювальних навичок в учнів початкової школи. Встановлено, шо у розвивальному навчанні визначна роль відводиться засвоєнню теорети чних знань для загального розвитку учнів.

На основі аналізу та співставлення авторських систем розвивального навчання визначено ефективні стратегії формування обчислювальних навичок в учнів початкової школи в сучасних умовах розробки нових методик.

Встановлено, шо розробка програми з математики з врахуванням кониепиії розвивального навчання має покласти в основу розуміння природи зв'язку психічного розвитку учнів зі змістом засвоюваних знань та умінь. Сам порядок представлення матеріалу має відповідати загальній логіиі побудови курсу з врахування психолого-нейрофрізіологічних особливостей учнів початкової школи.

Ключові слова: учні початкової школи; обчислювальні навички; розвивальне навчання; зона найближчого розвитку; обчислювальна діяльність; система навчальних завдань.

Постановка проблеми. В умовах сучасної освіти погляди психологів, дидактів, методистів зосереджені на пошуки найефективніших форм навчання. До них вчені зараховують розвивальне навчання. Загамом, на думку вчених всяке навчання сприяє розвиткові дитини, однак в одному випадку воно надбудовується над розвитком і здійснює стихійний вплив, а в іншому - цілеспрямовано забезпечує його та активно використовується дия засвоєння знань, умінь та навичок. У цьому сенсі дотримуємося думки $\Lambda$. Виготського, який вважав, що тільки те навчання в дитячому віці добре, яке забігає вперед розвитку i веде цей розвиток за собою [1].

Проблема розвивального навчання представцена у працях $\Lambda$. Виготського, П. Гальперіна, В. Давидова, Д. ЕАьконіна, А. Занкова, Н. Істоміної, А. Маркової, М. Скаткіна, М. Стєпанової, та ін. Самі ідеї розвивального навчання знайшли втілення у програмах навчання на методичних комплектах.

Метою статті $є$ визначення ефективних способів формування обчислювальних навичок в учнів початкової школи на основі теорії розвивального навчання.

Виклад основного матеріалу дослідження. Початок розробки теорії розвивального навчання розпочалася в $30-\mathrm{x}$ роках минулого століття після публікації праці $\Lambda$. Виготського "Розумовий розвиток дітей в процесі навчання" [1].

Вчений сформулював у цій роботі основні положення співвідношення навчання та розвитку і вказав на психологічні закономірності розвитку дитини - зону найближчого розвитку, обгрунтував можливість та доцільність навчання, орієнтованого на розвиток дитини, як на пряму і безпосередню його мету. $\Lambda$. Виготський також ввів у науковий обіг поняття рівенъ акту ального розвитку, який визначається за допомогою задач, які дитина може розв'язати самостійно, та зони найближчого розвитку, якого дитина досягає при розв'язуванні задач у співпраці із дорослим [2].

^. Виготський зазначив, що щось нове дитина зможе самостійно зробити після того, як виконала цю роботу у співпраці 3 іншими. Нова психічна фрункція з'явАяється у дитини в якості своєрідного індивідуального продовження їі виконання у колективній діяльності, організація якої і $є$ навчаннял. Розвиток будь-якої психічної функції, в тому числі і обчислень, відбувається через зону найближчого розвитку,

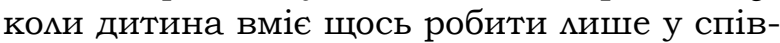


праці з дорослими, і мише потім переходить на рівень актуального розвитку, коли ця дія може виконувати самостійно [1;3, c. 250$]$.

Більш детальне пояснення щодо понять рівень актуального розвитку та зони найближчого розвитку знаходимо у працях А. Маркової. Вчена, опираючись на загальне поцоження $\Lambda$. Виготського вказує на те, що він виокремив в зоні найближчого розвитку підзону вмасної індивідуамьної активності учня - самонаучуваність, саморозвиток, самовиховання, яку і назвав зоною найближчого саморозвитку [4].

Якщо зона найближчого розвитку за $\Lambda$. Виготським - це відстань між рівнем його актуального розвитку, який визначається з допомогою задач, які розв'язуються учнем і рівнем можливого розвитку дитини, визначеним з допомогою задач, виконаних дитиною під керівництвом дорослого і при співпраці 3 розумним учнем [2, с. 247], то зону найближчого саморозвитку А. Маркова визначає як відстань між задачами, поставленими дорослими (розв'язуваними учнем у співпраці 3 дорослим) i самостійно поставленими, самостійно розв'язаними учнем задачами [4]. Ці ідеї було покладено в основу розвивального навчання, які представцені в авторських концепціях.

В основу своєї системи розвивального навчання $\Lambda$. Занков поклав теорію свого вчителя $\Lambda$. Виготського про те, що навчання веде за собою розвиток дитини і будується не тільки на завершених циклах розвитку, а перш за все на тих психічних функціях, які ще не дозріли та сприяє їх фрормуванню [5, с. 11].

При організації експериментального навчання $\Lambda$. Занковим викликалися різні форми розумової діяльності: спостереження та виокремлення суттєвих ознак та їх узагальнення. Важливим дия нашого дослідження, яке узгоджується з дослідженнями нейронаук, $\epsilon$ висновок $\Lambda$. Занкова, що внутрішні проиеси протікають за свойли власними законами, тобто відбувається об'єднання у функціональну систему різнохарактерних способів дії. На думку вченого саме це ї є вирішальним дия прогресу в розумовому розвитку дитини [5, с. 28].

3 метою формування обчислювальних навичок у системі $\Lambda$. Занкова застосовувався спосіб усвідомлення взаємовідношення арифметичних дій додавання та множення, віднімання та ділення. Учням даються запинання такого змісту: скіцьки разів треба взяти число 3 , щоб одержати 15; якщо 10 роздімити на 5 частин, то скільки у кожній буде [5, с.44]. За таким самим принципом відбувається вивчення множення та дімення (якщо число 5 збільшити в 3 рази, то буде 15; якщо 15 зменшити в 3 рази, то буде 5). При вивченні ділення багатоцифрового числа на багатоцифрове пояснення вчителя зводиться до того, щоб учні усвідомили, як використати вміння множення дільника на одноцифрове число [5, с. 45].

Загалом, технологія $\Lambda$. Занкова орієнтує учнів на участь у різних видах діяльності (дидактичних іграх, дискусіях і т.д.), а також використання у навчальному процесі таких методів, які спрямовані на розвиток уяви, мислення, пам'яті, мови [6, с. 176].

На відміну від традиційного навчання система розвивального навчання $\Lambda$. Занкова орієнтована на загальний розвиток школяра, який і $є$ метою навчання, а процес засвоєння знань, умінь та навичок відбувається у результаті просування учнів у загальному розвитку.

Вслід за $\Lambda$. Занковим експеримент $з$ реалізації розвивального навчання у початковій освіті був розпочатий Д. ЕАьконіним та його співробітниками. Згодом у співавторстві з В. Давидовим була створене система розвивального навчання, яка відрізнялася своєю дидактичною спрямованістю.

За задумом В. Давидова теоретичні знання як предмет навчальної діяльності засвоюється у результаті дослідницьковідтворюючих дій, спрямованих на змістове узагальнення [7; 8].

При побудові системи розвивального навчання В. Давидовим були використані погляди М. Скаткіна на проблеми тогочасного початкового навчання. Зокрема, він вважав, що молодші школярі можуть опановувати узагальненнями та поняттями теоретичного типу i засвоювати знання при вирішенні пізнавальних завдань. Такі знання учень має одержувати у процесі ї проблемного викладу, коли вчитель відтворює перед дітьми шлях їх відкриття. Відповідно до цієї теорії М. Скаткін відзначив, що повноцінне засвоєння теоретичних понять відбувається у процесі вирішення учнями навчальних задач, загальний зміст яких схожий з задачами, які у дидактиці називаються пізнавальними [9, с. 123-125]. Сама ж навчамьна діяльність пов'язана 3 продуктивним (творчим) мисленням шко$\Lambda я$ рів.

У концепції розвивального навчання В. Давидова зазначено, що основою розвивацьного навчання $\epsilon$ навчальна діяльність, базисом якої $є$ зміст, від якого похідні меmоди (чи засоби) організації цього навчання. Таке положення узгоджується з поглядами $\Lambda$. Виготського та Д. ЕАьконіна, відповідно до яких провідну роль у розумовому розвитку дитини здійснює навчання через зміст засвоюваних знань [10]. У по- 
ясненні до цього положення В. Давидов зазначив, що розвивальний характер навчальної діяльності, як основної діяльності, притаманної молодшому шкільному віку, пов'язаний з іï змістом, основою якого $\epsilon$ теоретичні знання [7, с. 144]. Відповідно до цього положення суть розвиваючого навчання можна представити у вигляді наступних положень: навчальна діяльність молодших школярів $є$ необхідною формою ï психічного розвитку; змістом навчамьної діяльності є теоретичні знання; засвоєння школярами теоретичних знань здійснюється в процесі розв'язання навчальних завдань за допомогою виконання певних дій.

Стрижнем навчального предмета, за визначенням В. Давидова, є його програма, яка $\epsilon$ систематичним і ієрархічним описом знань та умінь, які підлягають засвоєнню. Програма, яка фіксує зміст навчального предмета, визначає методи викладання, характер дидактичних посібників, терміни навчання та інші моменти навчального процесу. Істотною особливістю програми $є$ зазначений склад засвоюваних знань та їх зв'язок. Програма проектує той тип мисмення, який фрормується у школярів при засвоєнні ними запропонованого навчального матеріалу. Тому розробка програми, виділення змісту того чи іншого навчального предмета, зокрема математики, представ яє розуміння природи зв'язку психічного розвитку учнів зі змістом засвоюваних знань та умінь [7, с. 162].

В експериментальних навчальнометодичних матеріалах, розроблених вченими під керівництвом В. Давидова процес формування обчислювальних навичок мав певні особливості у порівнянні з традиційною методикою.

Так, при вирішенні першокласниками навчального завдання, що приводить їх до розуміння взаємозв'язку елементів арифметичних дій додавання та віднімання, діти спочатку знайомимися з відповідними операціями над величинами, фіксуючи їх вигляді просторово-графічних схем та мітерних формул. Потім при побудові відрізків діти з'ясовували таку властивість операції, як однозначність ї̈ структури, що призводить до наступного висновку: якщо відомо значення двох елементів операції, то завжди i однозначно можна визначити значення третього елемента. Вивчення дій додавання та віднімання супроводжується поясненням та розумінням рівняння. Це дозволяло побудувати на основі заданої рівності кілька видів рівнянь.

Формування обчислювальних умінь та навичок відбувається на основі попереднього засвоєння дітьми загальних закономірностей i властивостей тих чи інших арифметичних дій. У загальному вигляді діти попередньо розглядають можливість ї використання при обчисленнях різного виду і тільки потім приступають до виконання конкретних завдань на обчислення. Засвоєння дітьми обчислювальних прийомів відбувається за допомогою тренувальних карток, які побудовані таким чином, що спочатку вимагають від учнів повного, розгорнутого виконання всіх операцій обчислювального прийому, а потім забезпечують поступове згортання обчислень i мимовімьне запам'ятовування їх табличних випадків [7]. Окрім буквених моделей, важливу роль при формуванні математичних понять відіграють просторово-графічні моделі. Суттєвою їх особливістю $\epsilon$ об'єднання в них абстрактного змісту 3 предметною наочністю.

У представленій системі розвивального навчання моделювання пов'язане з наочністю, яку широко використовує традиційна дидактика. Однак в рамках експериментамьного навчання наочність має специфічний зміст. У наочних моделях знаходять відображення суттєві або внутрішні відношення і зв'язки об'єкта, виділені за допомогою відповідних перетворень [7, c. 183].

Процес засвоєння теоретичних знань забезпечується включенням у процес навчання еврестичних бесід, дослідницьких робіт (проектів), навчальних дискусій, пізнавальних ігор, використання технологій, які сприяють формуванню теоретичного мислення.

Варто зазначити, що серед діючих програм в Україні на даний час функціонують дві нетипові програми, в основу яких покмадена ідея розвивального навчання В. Давидова та Д. Эмьконіна: "Освітня програма за системою розвивального навчання Д. Б. Ельконініа, В. В. Давидова та ін." (автори I. Старагіна, Г. Захарова, Г. Жемчужкіна, К. Пінсон, О. Перепелиця, Н. Сосницька) (Харків), “Освітня програма дия закладів загальної середньої освіти за системою розвивального навчання (Центр психології і методики розвивального навчання" (автори С. Аомакович, $\Lambda$. Тимченко, С. Жукова, О. Кондратюк) (Київ) [11].

За винятком незначних відмінностей обидві програми при формуванні обчислювальних навичок опираються на теоретичне представлення матеріалу та розумінні числа як результату вимірювання величини, здійснюється опора на графічні (схеми) і знакові (формули) модемі.

У методичній системі авторства Н. Істоміної знаходимо визначення основних понять, пов'язаних з процесом формування обчислювальних навичок у молодших 
школярів. Цьому процесу вчена відводить особливу роль, зазначаючи, що формування обчислювальних умінь та навичок $€$ основним завданням початкового курсу математики. За іï визначенням обчислювальне уміння - це розгорнута здійснювана дія, у якій кожна операція усвідомлюються i контролюється. Обчислювальне уміння передбачає засвоєння обчислювального прийому. Обчислювальний прийом можна подати у вигляді послідовних операцій, виконання кожної з яких пов'язане з певним математичним поняттям або властивістю. На відміну від уміння навички характеризуються згорнутим та автоматизованим виконанням дій 3 пропуском проміжних операцій, коли контроль повинні засвоїти переноситься на кінцевий результат [12, c. 42].

На думку Н. Істоміної в початковому курсі математики на рівні навички учні повинні засвоїти: таблицю додавання/віднімання у межах 10; таблицю додавання одноцифрових чисел 3 переходом через розряд і відповідні випадки віднімання; таблицю множення і відповідні випадки дікення. Вчена зазначає, що засвоєння цих таблиць повинно бути доведено до автоматизму, інакше учні відчуватимуть труднощі в оволодінні обчислювальними уміннями, до складу яких в якості операцій входять обчислювальні навички [12, с. 43].

Важливим для нашого дослідження з точки зору методичних підходів щодо формування обчислювальних навичок у початковій школі є думка Н. Істоміної з приводу застосування 3 цією метою трьох різних підходів:

- заучування (зазубрювання) таблиць додавання і відповідних випадків віднімання, їх закріплення у процесі розв'язку завдань (пізнавальна діяльність при цьому буде характеризуватися активною роботою пам'яті і активізацією довільної уваги);

- учні знайомляться 3 різними обчислюва^ьними прийомами, самостійно складають таблиці і у довільному порядку запам'ятовують іх у процесі виконання різних вправ з обчислення;

- на відміну від попереднього прийому у певний час після виконання предметних дій і застосування обчислювальних прийомів учневі дається вказівка щодо запам'ятовування [12].

Як бачимо третій підхід є комбінацією другого та першого. Щодо ефективності кожного з них, то вчена наголошує, що визначити який 3 них в найбільш короткі терміни може забезпечити формування міцних обчислювальних навичок $є$ дискурсивним, оскільки це залежить від індивідуальних особливостей пам'яті і уваги моло- дшого школяра. Однак, опираючись на результати спостережень Н. Істоміна стверджує, що найбімьшою результативністю користується третій підхід [12, с. 44].

Думка вченої корелює з сучасними досмідженнями з нейрофізіології, що дмя виконання однієї і тієї ж діяльності, зокрема обчислювальної у різних мюдей залучаються різні ділянки мозку. Таким чином правомірною є iï думка про те, що учням можна дати вказівку щодо запам'ятовування таблиць додавання та віднімання, а можна орієнтувати їх на запам'ятовування складу кожного числа [12, с. 44]. Н. Істоміна пропонує формування обчислювальних навичок дия випадків додавання та віднімання організовувати за наступними етапами: підготовка до ознайомлення 3 новим прийомом; ознайомлення 3 новим обчислюваАьним прийомом, коли подається зразок дій; складання таблиць 3 допомого обчисмювальних прийомів; установка на запам'ятовування таблиць; закріплення табАиць у процесі тренувальних вправ [12, c. 44].

У методичній системі Н. Істоміної прийом додавання одноцифрових чисел з переходом через розряд вкцючає наступні операції: доповнення більшого 3 доданків до числа 10; усвідомлення учнями змісту дій додавання та віднімання і засвоєння ними скмаду одноцифрових чисел і $з$ опорою на ці знання визначають скільки одиниць залишилося у другому доданку після того як виконана перша операція; одиниці, які залишимися від другого доданку додають до числа 10.

Вчена зазначила, що для оволодіння даним прийомом необхідне міцне засвоєння складу числа у межах 10 і складу двоцифрового числа 3 десятків та одиниць. Дия нас важливою $є$ думка Н. Істоміної про те, що цей прийом можна представити у вигляді тотожних перетворень.

\section{Наприклад:}

$7+6=7+(3+3)=(7+3)+3=10+3=13$.

При його виконанні застосовується сполучна властивість, або правило додавання до числа суми. Однак, вчена, опираючись на практичні спостереження, зазначима, що більшість семимітніх дітей мають труднощі 3 виконнанням такого громіздкого запису, а тому доцімьно використовувати інші форми запису.

\section{Hаприклад:}

$$
\begin{array}{cc}
8+7=15 & 8+7=15 \\
2 & 8+2+5=15
\end{array}
$$

Число 2 показує, яке число треба додати до 8, щоб одержати число 10. Число 5 показує скільки одиниць треба додати до $10[12$, c. 63]. 
Такий підхід узгоджується 3 психологічними дослідженнями В. Давидова, який відводить особливу принципу моделювання, що не суперечить принципу наочності, оскільки є його вищим рівнем узаальненості [13, с. 53].

Такі міркування узгоджуються також 3 нейропсихологічними дослідження, оскльки за їх даними у віці 7-8 років відбувається активне дозрівання скроневотім'яно-потиличної зони, які забезпечують запам'ятовування і розпізнання зорових об'єктів на основі їх семантичних характеристик і пов'язані зі здійсненням когнітивних операцій. Також у цей час у мівій півкулі активізується сприйняття таблиць додавання і множення та опорних схем [14, c. 26-31].

Цілком погоджуємося з думкою Н. Істоміної, що табличні випадки множення та відповідні їм випадки ділення повинні бути засвоєні на рівні навички. Оскільки це складний та довготривалий процес, то в ньому вчена виокремлює два основні етапи: складання таблиць та їх засвоєння.

Складанню цих таблиць передує вивчення теоретичної основи обчислювальних прийомів, які будуть необхідні дмя складання цих таблиць. До них належать: зміст дії множення як суми однакових доданків, переставна вцастивість множення, взаємозв'язок компонентів і результату множення, зміст дії дімення. Однак вчена зазначає, що послідовність складання табмиць та організація обчислювальної діяльності з їх засвоєння може бути різною [12, c. 87-88].

Так, знайомство з розподільним законом множення, переставним та сполучним обумовцений могікою побудови курсу, тобто подаються не в усіх методичних комплектах не однаково. Зокрема можливий і такий випадок, коми термін розподімьна властивість множення не вводиться безпосередньо, а натомість розглядаються два правима: множення суми на число; множення числа на суму.

Вивчення таких правим розведене в часі, оскільки перше межить в основі обчис$\Lambda$ ювального прийому множення двоцифрового числа на одноцифрове (у межах 100), а друге вводиться дия пояснення способу дій при множенні двоцифрового числа на двоцифрове (письмове множення "у стовбчик").

Висновки і перспективи подамьших досліджень. Аналіз авторських концепцій розвивального навчання уможливив висновок, що при висвітленні окремих тем не існує загального підходу до їх подання. Однак, порядок їх представлення має від- повідати загамьній могіці побудови курсу 3 врахування психолого-нейрофізіологічних особливостей молодших школярів. У дослідженні саме цього аспекту вбачаємо перспективи подальших розвідок у напрямку формування обчислювальних навичок учнів початкової школи.

\section{Список бібціографічних посимань}

1. Виготський $\Lambda . С$. Розумовий розвиток дітей в процесі навчання. Педагогічна психологія, 1991. № 10. C. 334-430.

2. Выготский М.С. Собрание сочинений: В 6 т. Т.3: : Пробцемы развития психики. М.: Педагогика. 1984. 369 c.

3. Выготский $\Lambda$.С. Собрание сочинений: В 6 т. Т.2: Проблемы общей психологии. М.: Педагогика. 1982.504 c.

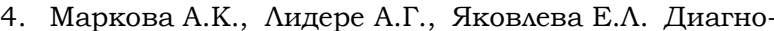
стика и коррекция умственного развития в школьном и дошкольном возрасте. Петрозаводск, 1992. $180 \mathrm{c}$.

5. Занков А.В. Развитие учащихся в процессе обучения (1-2). М.: Изд-во АПН РСФСР, 1963. 293 с.

6. Дичківська I.М. Інноваційні педагогічні технології: навч. посібник. Київ: Академвидав, 2004. 352 с.

7. Давыдов В.В. Проблемы развивающего обучения. Опыт теоретического и экспериментального психологического исследования. М.: Наука, 1986. $240 \mathrm{c}$.

8. Давыдов В.В. Теория развивающего обучения. М.: ИНТОР, 1996. 544 с.

9. Скаткин М.Н. Совершенствование процесса обучения. М.: Педагогика, 1971, 208 с.

10. Эльконин Д.Б. Интелмектуальные возможности младших школьников и содержание обучения. Возрастные возможности усвоения знаний (младшие классы школы). Под ред. Д.Б. Эмьконина, В.В. Давыдова. 1966. С. 47-48.

11.У школах можна буде навчати за 8 програмами, що не є типовими - висновок держслужби якості освіти. URL: https://mon.gov.ua/ua/news/ushkolah-mozhna-bude-navchati-za-8-programi-shone-ye-tipovimi-visnovok-derzhsluzhbi-yakosti-osviti (дата звернення 24.07. 2020).

12. Істоміна $\mathrm{H}$. Методика обучения математике в начальных классах: Учеб. пособие дмя студ. сред. и высш. пед. учеб. заведений. 4-е изд., стереотип. М.: Академия, 2001. 288 с.

13. Фридман $\Lambda$. М. Психолого-педагогические основы обучения математике в школе: Учителю математики о педагогической психологии. М.: Просвещение, 1983. 160 с.

14. Сігел Д., Брайсон Т. Секрети мозку. 12 стратегій розвитку дитини. Пер. з анг. Ірина Борщ. Київ: Наш формат, 2017. 192 c.

15. Skvortsova S., Romanyshyn R. (2019). The Computational Activity of Younger Students: Neuropsychological Approach. Universal Journal of Educational Research, 2019. 7(12), 2817-2829. DOI: 10.13189/ujer.2019.071232.

\section{References}

1. Vygotsky, L.S. (1991). The mental development of children in the learning process. Pedagogical Psychology, 10, 334-430 [in Ukr. ].

2. Vygotsky, L.S. (1984). Collection of works: In 6 vol. Vol. 3: Mental development problems. Moscow: Pedagogy. 369 p. [In Rus.].

3. Vygotsky, L.S. (1982). Collection of works: In 6 vol. Vol. 2: Problems of general psychology. Moscow: Pedagogy. P. 250 [In Rus.].

4. Markova, A.K., Lidere A.G., Yakovleva Ye.L. (1992). Diagnostics and correction of mental development at school and preschool age. Petrozavodsk. 180 p. [In Rus.]. 
5. Zankov, L.V. (1963). Development of learners in the learning process (1-2). Moscow: Publishing House APS RSFSR. 293 p. [In Rus.].

6. Dychkivska, I.M. (2004). Innovation pedagogical technologies: Course book. Kyiv: Akademvydav. 352 p. [in Ukr. ].

7. Davydov, V.V. (1986). Problems of developing education. The experience of theoretical and experimental psychological research. Moscow: Science. 240 p. [In Rus.].

8. Davydov, V.V. (1996). The theory of developing education. Moscow: INTOR. 544 p. [In Rus.].

9. Skatkin, M.N. (1971). Improving the learning process. Moscow: Pedagogy. 208 p. [In Rus.].

10. Elkonin, D.B. Intellectual opportunities of younger students and the content of education. Age opportunities for the assimilation of knowledge (primary school). In D.B. Elkonin, V.V. Davydov (Eds.). 47-48. [In Rus.].

11. Schools can have 8 programs, which are not typical: the report of the State Service for Education. Re- trieved 24.07.2020, from https://mon.gov.ua/ua /news/u-shkolah-mozhna-bude-navchati-za-8programi-sho-ne-ye-tipovimi-visnovok-derzhsluzhbiyakosti-osviti. [in Ukr.].

12. Istomina, N. (2001). Methods of teaching mathematics in primary grades: Textbook for students of secondary and higher pedagogical educational institutions. 4th ed., Stereotype. Moscow: Academy. 288 p. [In Rus.].

13. Fridman, L.M. (1983). Psychological and pedagogical foundations of teaching mathematics at school: To the teacher of mathematics about ped. psychology. Moscow: Education. 160 p. [In Rus.].

14. Sihel, D., Braison, T. (2019). Brain secrets. 12 strategies of child's development. In I. Borshch (transl.). Kyiv: Our format. 192 p. [in Ukr. ].

15. Skvortsova, S., Romanyshyn, R. (2019). The Computational Activity of Younger Students: Neuropsychological Approach. Universal Journal of Educational Research, 7(12), 2817-2829. DOI: $10.13189 /$ ujer.2019.071232.

\section{ROMANYSHYN Ruslana,}

Ph.D in Pedagogy, Associate Professor of Specialist Methods and Technologies of Elementary Education Department, SIHE "Vasyl Stefanyk Precarpathian National University"

\section{FORMATION OF COMPUTING SKILLS IN PRIMARY SCHOOL STUDENTS IN CONDITIONS OF DEVELOPMENTAL LEARNING}

Summary. Introduction. The process of mastering the content of computing activities and the formation of computing skills on its basis is a complex and lengthy process. For this process to be more successful, it must be consistent with the objective laws of knowledge acquisition and the laws of psychic, in particular, mental development. In the conditions of modern education there is a search for the most effective forms of education to which scientists include developmental training. Purpose. Identify effective ways to develop computing skills in primary school students.

Methods. Analysis of psychological and pedagogical, mathematical, educational and methodical literature, legislative and regulatory documents governing the system of primary education; generalization of theoretical and experimental data.

Results. Theoretical principles of developmental learning from the point of view of activity theory are covered. There is a difference between the process of forming computing skills in the traditional system of education and the system of developmental learning. Characteristic features of systems of L. Zankov, V. Davydov and D. Elkonin, N. Istomina are noted. As a result of the analysis, effective strategies for the formation of computing skills in primary school students are named. It is established that in devel- opmental learning a significant role is given to the acquisition of theoretical knowledge for the general development of students.

Originality. Based on the analysis and comparison of the author's systems of developmental learning, effective strategies for the formation of computing skills in primary school students in modern conditions of development of new methods are determined.

Conclusion. It was found that the development of a program in mathematics, taking into account the concept of developmental learning, should be based on understanding the nature of the relationship between psychic development of students with the content of acquired knowledge and skills. The very order of presentation of the material should correspond to the general logic of building a course taking into account the psychological and neurophysiological characteristics of primary school students.

Keywords: primary school students; computing skills; developmental learning; the zone of the nearest development; computing activities; system of educational tasks.

Одержано редакиією 10.12 .2020 Прийнято до публікаиії 20.12.2020 